\title{
COMPARISON OF LAM-ICP-MS AND MICRO-PIXE RESULTS FOR PALLADIUM AND RHODIUM IN SELECTED SAMPLES OF NORIL'SK AND TALNAKH SULFIDES
}

\author{
LOUIS J. CABRI ${ }^{\S}$ \\ Canada Centre for Mineral and Energy Technology, 555 Booth Street, Ottawa, Ontario K1A OG1, Canada, \\ and Department of Earth Sciences, Memorial University of Newfoundland, St. John's, Newfoundland A1B 3X5, Canada \\ Paul J. SYLVESTER ${ }^{\mathbb{I I}}$ AND Michael N. TUBRETT \\ Department of Earth Sciences, Memorial University of Newfoundland, St. John's, Newfoundland A1B 3X5, Canada
}

ANIA PEREGOEDOVA

Department of Earth Sciences, Carleton University, Ottawa, Ontario K1S 5B6, Canada, and Institute of Mineralogy and Petrography, Siberian Branch of the Russian Academy of Sciences, Novosibirsk 630090, Russia

\section{J.H. GILLES LAFLAMME}

Mining and Mineral Sciences Laboratories, Canada Centre for Mineral and Energy Technology, 555 Booth Street, Ottawa, Ontario K1A OG1, Canada

\begin{abstract}
Comparisons of PGE measurements by laser-ablation microprobe (LAM-ICP-MS) with micro-PIXE analyses on the same sulfide grains were made in order to assess data quality. Pyrrhotite, pentlandite and chalcopyrite from a few samples of disseminated ores of the Noril'sk I intrusion and massive ore from the Talnakh deposit, Russia, were analyzed for Pd and Rh by microPIXE and for all PGE by LAM-ICP-MS. Micro-PIXE analyses employed focused proton beams of $8 \times 15 \mu \mathrm{m}$ for grains in heavy-mineral separates and $15 \times 20 \mu \mathrm{m}$ for grains in hand samples. These represent analyzed volumes of about $2,350 \mu \mathrm{m}^{3}$ in pyrrhotite and 5,900 $\mathrm{mm}^{3}$ for Pd in pentlandite. LAM analyses were performed with a focused, 266-nm laser beam fired at $0.3 \mathrm{~mJ} /$ pulse and $10 \mathrm{~Hz}$, resulting in 35-40 $\mu \mathrm{m}$ spots and analyzed volumes of about $85,000 \mu \mathrm{m}^{3}$. Fused pyrrhotite standards separately doped with Pd, Ru, and Rh were synthesized for LAM-ICP-MS, and calibrated against sintered pyrrhotite PGE standards of Ballhaus \& Sylvester (2000). The level of Pd, Ru and Rh varies by $\sim 4$ to $9 \%(1 \sigma)$ in the fused pyrrhotite standards at a 50- $\mu \mathrm{m}$ sampling scale. The LAM and micro-PIXE results for the natural sulfides are quite comparable, with the large majority of determinations falling within 33\% of each other for both $\mathrm{Pd}$ and $\mathrm{Rh}$ on the same spot. This agreement is considered encouraging for use of the LAM-ICP-MS for trace PGE analysis, considering the large differences in volumes analyzed, and in probable trace-element heterogeneity in the grains and standards. The reasonable concordance of most Pd and Rh results by LAM-ICPMS and micro-PIXE indicates the potential of the LAM-ICP-MS technique. LAM analyses of the natural sulfides for Pt, Ir and Os were made using the standards of Ballhaus \& Sylvester (2000). Platinum is more enriched in pentlandite $(n=10)$ than in pyrrhotite ( $3.2 \pm 1.2$ versus $0.73 \pm 0.60 \mathrm{ppm}$ ) from Noril'sk (MP6-97), but $\operatorname{Ir}(0.94 \pm 0.32$ versus $1.38 \pm 0.13$ ppm) is only slightly higher in pyrrhotite $(n=10)$, whereas Os $(\sim 0.5 \mathrm{ppm})$ is comparably enriched in both minerals. Noril'sk chalcopyrite contains trivial amounts of all PGE except Pd (6.6-15 ppm).
\end{abstract}

Keywords: laser-ablation microprobe, ICP-MS, micro-PIXE, electron-probe micro-analysis, PGE standards, synthesis, sulfide minerals, palladium, rhodium, ruthenium, Noril'sk, Talnakh, Russia.

\section{SOMMAIRE}

Nous avons effectué une comparaison des mesures de concentrations des éléments du groupe du platine (EGP) par ablation au laser avec la méthode ICP-MS et par analyses micro-PIXE des même grains de sulfures, afin d'évaluer la qualité des données. La pyrrhotite, la pentlandite et la chalcopyrite de quelques échantillons de minerai disséminé provenant de l'intrusion Noril'sk I, et

$\S \quad$ Postal address: 99 Fifth Avenue, Suite 122, Ottawa, Ontario K1S 5P5, Canada. E-mail address: 1cabri@sympatico.ca II E-mail address: pauls@sparky2.esd.mun.ca

¥ Present address: Department of Earth and Planetary Sciences, McGill University, Montreal, Quebec H3A 2A7, Canada. 
de minerai massif du gisement de Talnakh, en Russie, ont été analysées pour le Pd et le Rh par technique micro-PIXE, et pour tous les éléments du groupe par la technique LAM-ICP-MS. Les analyses micro-PIXE ont été faites avec des faisceaux focalisés de protons de $8 \times 15 \mu \mathrm{m}$ dans le cas de grains d'un concentré de minéraux lourds, et de $15 \times 20 \mu \mathrm{m}$ dans le cas de grains des échantillons. Les volumes analysés correspondants sont d'environ $2,350 \mu \mathrm{m}^{3}$ dans la pyrrhotite et $5,900 \mu \mathrm{m}^{3}$ pour le Pd dans la pentlandite. Les analyses par ablation au laser ont utilisé un faisceau laser focalisé de $266 \mathrm{~nm}$ à un taux de $0.3 \mathrm{~mJ}$ par décharge à $10 \mathrm{~Hz}$, ce qui a créé des cratères de 35-40 $\mu \mathrm{m}$ et des volumes analysés d'environ $85,000 \mu \mathrm{m}^{3}$. Des étalons de pyrrhotite fondue dopés avec Pd, Ru, et Rh ont été synthétisés pour les analyses LAM-ICP-MS, et le calibrage s'est fait par rapport aux étalons EGP de pyrrhotite recuite de Ballhaus et Sylvester (2000). Les teneurs en Pd, Ru et Rh varient par moins de 4 à $9 \%(1 \sigma)$ dans les étalons de pyrrhotite fondue à une échelle d'échantillonnage de $50 \mu \mathrm{m}$. Les résultats obtenus pour les sulfures naturels par ablation au laser et par micro-PIXE se comparent bien, les déterminations étant concordantes à 33\% ou mieux pour Pd et Rh sur la même cible, dans la grande majorité des cas. Nous considérons cette concordance encourageante pour l'utilisation éventuelle de la technique LAM-ICP-MS pour l'analyse d'échantillons contenant des quantités infimes des EGP, compte tenu des grandes différences des volumes analysés, et de l'hétérogénéité probable dans la distribution des éléments traces autant dans les grains que dans les étalons. La concordance raisonnable de la plupart des résultats sur le Pd et le Rh par LAM-ICP-MS et par micro-PIXE souligne le potentiel de la technique LAM-ICP-MS. Les analyses par ablation au laser des minerais pour Pt, Ir et Os ont été faites avec les étalons de Ballhaus et Sylvester (2000). Ici, le platine est davantage enrichi dans la pentlandite $(n=10)$ par rapport à la pyrrhotite $(3.2 \pm 1.2$ versus $0.73 \pm 0.60 \mathrm{ppm})$ dans l'échantillon MP6-97 de Noril'sk, mais l'Ir $(0.94 \pm 0.32$ versus $1.38 \pm 0.13 \mathrm{ppm})$ n'est que légèrement enrichi dans la pyrrhotite $(n=10)$, tandis que l'Os $(\sim 0.5 \mathrm{ppm})$ est enrichi dans les deux minéraux de façon comparable. La chalcopyrite de Noril'sk contient des quantités infimes de tous les EGP sauf le Pd (6.6-15 ppm).

(Traduit par la Rédaction)

Mots-clés: microsonde par ablation au laser, ICP-MS, micro-PIXE, analyses à la microsonde électronique, étalons EGP, synthèse, minéraux sulfurés, palladium, rhodium, ruthénium, Noril’sk, Talnakh, Russie.

\section{INTRODUCTION}

Quantitative measurements of the concentrations of platinum-group elements (PGE: Pt, Pd, Rh, Ru, Ir, Os) in sulfide minerals are important to understand magmatic-hydrothermal processes in ore-genesis studies, for vectoring to ore in exploration programs, and for optimizing mineral liberation and recovery during mineral processing and metallurgical treatment. Analyses of bulk sulfide concentrates for the PGE have been traditionally used for this purpose (e.g., Chen et al. 1996). However, neither ore microscopy, nor searches by scanning electron-microscope-based image analysis (e.g., Lastra et al. 1999) can provide a reliable value for the PGE concentrations of individual host phases, commonly sulfide, arsenide and sulfarsenide minerals. Such methods can provide the spatial distribution of PGE present in sulfides as tiny inclusions of platinum-group minerals (PGM), but only approximate estimates can be made of PGE occurring as a solid solution or trapped as submicrometric particles, and usually not for individual minerals. In situ analyses by microbeam methods are thus preferred. Micro-PIXE, the proton-induced X-ray emission or "proton" microprobe, is a microbeam method often employed for this work. In this method, a charged beam of particles is focused on a sample surface and induces an emission of X-rays that are characteristic of particular elements, whose concentration can be quantified by reference to external calibration standards. An advantage of micro-PIXE is the ability to analyze small spots, typically 5 to $15 \mu \mathrm{m}$ in diameter, as well as the ability to obtain quantitative trace-element data for most elements with $\mathrm{Z}>\mathrm{Fe}$, except that detection sensitivity is limited for As- or Pb-rich minerals (Cabri \& Campbell 1998). External calibration is easily achieved using readily available materials, such as ironbased alloy NIST 1155. A significant limitation of micro-PIXE, however, is that detection limits for the light PGE (Ru, Rh, Pd) in sulfides are $\sim 5 \mathrm{ppm}$, and are much higher for the heavy Pt, Ir and Os, thus above the levels found in many natural samples. Another method that has been used to determine PGE in sulfide minerals at the sub-ppm level is secondary ion mass spectrometry (SIMS), but disadvantages of the method are the cost and need to prepare single-element standards for each matrix to be analyzed, as well as the scarcity of laboratories with mineralogical expertise (McMahon \& Cabri 1998). However, an advantage of SIMS is the ability to make ion images to show the distribution of specific trace elements.

The laser-ablation microprobe - inductively coupled plasma - mass spectrometer (LAM-ICP-MS) holds great promise as a microbeam method for PGE analysis of sulfides. With it, one has the ability to make quantitative measurements of PGE in sulfides at levels as low as a few tens of parts per billion, depending on the element measured (heavy PGE have lower detection-limits than light PGE), and the spot size used (larger spots reduce the detection limit). Sample volumes are larger than for micro-PIXE or SIMS in that laser-spot sizes are typically 40 to $75 \mu \mathrm{m}$, and the laser drills down into the sample, creating a pit with a depth comparable to the width. A gas stream carries the ablated material from the pit to the plasma source for analysis by quadrupole 
mass spectrometry. LAM-ICP-MS has been used for analyses of lithophile metals in silicate minerals with great success for some time (Jackson et al. 1992), but there have been fewer reports of PGE measurements in sulfides (Alard et al. 2000, Ballhaus \& Sylvester 2000). The principal reason for the slow development of LAMICP-MS for PGE analyses has been the lack of suitable standard materials needed for external calibration. Ballhaus \& Sylvester (2000) produced polycrystalline $\mathrm{Fe}_{1-x} \mathrm{~S}$ sinters, each spiked with a single PGE 5-10 ppm levels, and used them as calibration standards for analysis of natural sulfides from the Merensky Reef, South Africa. However the limited amount of material produced is now entirely depleted, requiring synthesis of new reference materials.

In this study, we generated new reference materials for Pd, Rh and Ru consisting of synthetic fused pyrrhotite, and employed them as standards for LAM-ICPMS analyses of these PGE in natural pentlandite, pyrrhotite and chalcopyrite from the Noril'sk and Talnakh ore deposits, Russia. We did not generate standards for the heavy PGE in this study, but report new data for Ir, Pt and Os on the Noril'sk and Talnakh ore samples, calibrated against the sintered standards of Ballhaus \& Sylvester (2000). Because reliable values had been obtained by micro-PIXE (Cabri 1998, Cabri et al. 2002), where concentrations of $\mathrm{Pd}$ and $\mathrm{Rh}$ were sufficiently high, analyses were made on some of the same sets of samples. This approach allowed, for the first time, direct comparisons of PGE measurements by LAM-ICP-MS and micro-PIXE on the same sulfide grains. Comparisons for $\mathrm{Ru}$ and the heavy PGE were not possible because the detection limits for these elements by PIXE were not sufficiently low.

\section{SAMPLES}

The Noril'sk sulfides we have studied come from disseminated ores in picrites and gabbro-dolerites in the western part of the open pit of the Medevezhiy Ruchei mine, Noril'sk-1 deposit, $180 \mathrm{~m}$ level, consisting of heavy-mineral separates (KH97-3) and a hand sample (MP6-97 series). In addition, we studied a hand sample of massive ore from an unknown location at Talnakh (9501-A). Sample locations for the Noril'sk samples are shown in Distler et al. (1999, Fig. 5) and in Cabri et al. (2002, Fig. 1). The MP6-97 and 9501-A series were collected by Dr. V.V. Distler, then cut into slices for polished sections as previously studied and reported by Cabri (1998).

The geology and mineralogy of the Medevezhiy Ruchei mine were described by Distler et al. (1999), and the deposits and PGE mineralization of the Noril'sk area, by Genkin (1968) and Distler (1994). The geology of the deposits in the Talnakh area has been described by many authors (e.g., Likhachev 1999), and the mineralogy, most recently by Kozyrev et al. (2002). The
KH97-3 series sample was ground, sieved, and the sulfide minerals concentrated using heavy liquids (Cabri et al. 2002). The sulfide concentrates were prepared into polished sections and examined by optical microscopy to locate grains of pentlandite, pyrrhotite and chalcopyrite suitable for electron-probe micro-analyses (EPMA), micro-PIXE analyses and LAM-ICP-MS analyses.

\section{Synthesis of Fused Pyrrhotite Standards}

A S-rich composition of about $37.4 \mathrm{wt} . \% \mathrm{~S}$ was chosen for synthesis of the PGE-bearing pyrrhotite standards. Three samples of pyrrhotite, separately doped with $\mathrm{Pd}, \mathrm{Rh}$ and $\mathrm{Ru}$ (Po-2, $\mathrm{Po}-5$ and $\mathrm{Po}-8$, respectively), were synthesized in evacuated silica glass tubes using the following pure elements: iron foil (Puratronic, 99.995\%), pieces of sulfur (Puratronic, 99.999\%), palladium tube (high purity $99.99 \%$ ), rhodium powder (Premion, 99.99\%), ruthenium powder (Premion, $99.99+\%)$. We used double silica glass tubes to avoid oxidation of the samples during melting in the case of breakage of the inner tube containing the charge. After preheating a mixture of the elements at $340^{\circ} \mathrm{C}$ for $3-4$ days until complete visual disappearance of elemental sulfur from the tube, the charges were fused at $1205^{\circ} \mathrm{C}$ in a vertical furnace. They were kept for 30 minutes at the melting temperature to assure complete reaction and mixing of the elements. The temperature was then reduced to $1000^{\circ} \mathrm{C}$ at a rate of $1^{\circ} \mathrm{C}$ per minute, annealed for 4 days, and quenched by dropping the tubes into cold water. The time for initiation of quenching is estimated to be about 3 seconds. The pyrrhotite samples synthesized were then mounted in polished sections and checked for homogeneity under optical and electron microscopes, using back-scattered electrons and high magnification. No PGE-bearing phases were observed to have exsolved in the pyrrhotite matrix.

\section{EPMA AND Micro-PIXE ANALYSES}

All the EPMA were performed at CANMET, using two instruments. The analyses of the KH97-3 sample were done using a JEOL 8900 instrument by D. Kingston [see Cabri et al. (2002) for details]. A JEOL 733 electron microprobe using wavelength-dispersion spectrometry, operated at $20 \mathrm{kV}$, with a beam current (cup reading) of $20 \mathrm{nA}$, was used for the synthetic pyrrhotite and the sulfides in samples MP6-97 and 9501A. The following X-ray lines and standards were used for the synthetic pyrrhotite: $\mathrm{Fe} K \alpha$ and $\mathrm{S} K \alpha$ (synthetic $\mathrm{Fe}_{6.97} \mathrm{Rh}_{0.03} \mathrm{~S}_{8.0}$, CANMET no. 481$), \operatorname{Pd} L \alpha, \operatorname{Rh} L \alpha$ and $\mathrm{Ru} L \alpha$ (metals). Counting time was of the order of $100 \mathrm{~s}$ for the trace elements, and raw-data corrections for ZAF were applied. For the Noril'sk and Talnakh sulfides, the following X-ray lines and standards were used: $\mathrm{Fe} K \alpha$, $\mathrm{Ni} K \alpha$ and $\mathrm{S} K \alpha$ (synthetic $\mathrm{Fe}_{4.0} \mathrm{Ni}_{5.0} \mathrm{~S}_{7.99} \mathrm{Se}_{0.01}$, CANMET no. 538 and synthetic $\mathrm{Fe}_{6.97} \mathrm{Rh}_{0.03} \mathrm{~S}_{8.0}$, CANMET 
no. 481) and $\operatorname{Co} K \alpha$ (CANMET synthetic $\operatorname{CoS}_{2}$ ). Counting time was of the order of $60 \mathrm{~s}$ for the minor elements, and raw-data corrections for ZAF were applied.

The samples of fused synthetic pyrrhotite, $\mathrm{Po}-2$, $\mathrm{Po}-$ 5 , Po-8, have quite homogeneous major-element compositions. Twenty-five spot analyses on each pyrrhotite indicated mean $\mathrm{S}$ and Fe contents of: $37.40 \pm 0.17$ and $63.28 \pm 0.20$ wt. \% for Po-2, $37.63 \pm 0.17$ and $63.35 \pm$ 0.19 wt. \% for Po-5, and $37.51 \pm 0.16$ and $63.31 \pm 0.20$ wt.\% for Po-8. The pyrrhotite in sample KH97-3 has a mean composition $(n=51)$ of $\mathrm{Fe} 58.88 \pm 0.6, \mathrm{~S} 39.86 \pm$ 0.2 , Ni $1.63 \pm 0.25, \mathrm{Cu} 0.3 \pm 0.1$, Co $0.3 \pm 0.4$, total 100.97 wt. \%. The analytical results on sulfides in samples MP6-97 and 9501-A are reported in Laflamme (2000).

Micro-PIXE analyses were done at the University of Guelph using focused $3 \mathrm{MeV}$ proton beams of $8 \times$ $15 \mu \mathrm{m}$ for grains in heavy-mineral separates; the collected beam charge at each spot was $3.375 \mu \mathrm{C}$. The current varied with the mineral analyzed over the range 6.3 to $13.1 \mathrm{nA}$ for analysis times of 257 to $534 \mathrm{~s}$. In order to obtain lower levels of detection, which were possible in the more massive grains in the hand samples, a larger beam-size of $15 \times 20 \mu \mathrm{m}$ was used, and the collected beam-charge at each spot was $5.0 \mu \mathrm{C}$. The current varied with the mineral analyzed over the range 6.5 to $16.2 \mathrm{nA}$ for analysis times of 308 to $775 \mathrm{~s}$. These represent analyzed volumes of about $2,350 \mu^{3}$ in pyrrhotite for the KH97-3 sample, and larger volumes for the hand samples, from $5,900 \mu^{3}$ for pentlandite to about $6,700 \mu^{3}$ for chalcopyrite, using calculated depths for $90 \% \mathrm{X}$-ray yields given in Table 1 of Cabri \& Campbell (1998). Micro-PIXE data for sulfide grains in KH97-3 are reported by Cabri et al. (2002); for sulfide grains in samples MP6-97 and 9501-A, the data are given in Cabri (1998).

\section{LAM-ICP-MS ANALYSES}

\section{Instrumentation}

LAM-ICP-MS analyses employed a Fisons VG PlasmaQuad 2S+ ICP-MS instrument coupled to an inhouse-built $266 \mathrm{~nm} \mathrm{Nd-YAG} \mathrm{laser} \mathrm{at} \mathrm{Memorial} \mathrm{Uni-}$ versity of Newfoundland (MUN). The ICP-MS is equipped with a fast-switching quadrupole mass filter and a single Galileo-type electron multiplier. Ablation sites on the grains were selected for analysis by viewing through a TV camera. For most analyses, the carrier gas was helium, fed continuously through the ablation cell and combined with argon just before entering the torch. Ablation in helium minimized the fallback of ablated material around the pit, and efficiently carried that material to the argon plasma. Nebulizer flow-rates for the ICP were $0.74 \mathrm{~L} / \mathrm{min} \mathrm{He}$ and $0.67 \mathrm{~L} / \mathrm{min} \mathrm{Ar}$. Analyses were performed using a focused laser beam of $0.3 \mathrm{~mJ} / \mathrm{pulse}$ (measured just before the beam entered the objective of the microscope), and a laser-repetition rate of $10 \mathrm{~Hz}$, which produced a spot $35-40 \mu \mathrm{m}$ in diameter on the sample. Under these conditions, the instrument had a sensitivity of $\sim 1000 \mathrm{cps} / \mathrm{ppm}$ for the mono-isotopic ${ }^{103} \mathrm{Rh}$.

\section{Data collection}

The data were acquired in time-resolved - peakjumping - pulse-counting mode with one point measured per peak for masses 33 (S fly-back peak, used to increase the quadrupole settling-time after the jump from high to low mass in each sweep), 34 (S), 59 (Co), $65(\mathrm{Cu}), 66(\mathrm{Zn}), 99(\mathrm{Ru}), 101(\mathrm{Ru}), 103(\mathrm{Rh}), 105(\mathrm{Pd})$, 106 (Pd), 108 (Pd), 111 (Cd), 188 (Os), 189 (Os), 191 (Ir), 193 (Ir), 194 (Pt) and 195 (Pt). [An attempt to collect data for mass $61(\mathrm{Ni})$ was made in early analyses, but abandoned when high count-rates for this isotope in numerous samples caused the detector to exceed its operational threshold and "trip" off during data acquisition.] The internal standard element was S (using mass 34), whose concentration was determined from EPMA. Internal standardization is required to correct for different ablation-yields from spot to spot, and for variations in instrument sensitivity over time (drift). Masses representing $\mathrm{Co}, \mathrm{Cu}, \mathrm{Zn}$ and $\mathrm{Cd}$ were monitored for spectral interferences (see below). Quadrupole settling-time was $1 \mathrm{~ms}$, and the dwell time was $8.3 \mathrm{~ms}$ on each mass.

The methodology employed an analytical sequence of two analyses for each of the three fused synthetic pyrrhotite standards, then analyses of 16 unknown sulfide particles, closing with a repetition of two analyses each of the pyrrhotite standards. In some runs, duplicate analyses of each of the Ir, Pt and Os sintered sulfide standards of Ballhaus \& Sylvester (2000) also were made. Data were collected in five separate analytical sessions over three days. An additional set of four experiments was conducted over three days to cross-calibrate the Pd, Rh and Ru contents of the new fused pyrrhotite standards against the sintered pyrrhotite standards of Ballhaus \& Sylvester (2000).

Most ablations lasted for about 60 seconds, resulting in analyzed volumes of about $85,000 \mu \mathrm{m}^{3}$ on the 35-40 $\mu \mathrm{m}$ diameter spots. Typical data-acquisitions consisted of a 60 -second measurement of the gas blank prior to ablation. An example of a typical spectrum for pentlandite from this study is shown in Figure 1A. In some cases, the laser drilled down through one sulfide phase into another, and this was immediately obvious, as shown in the spectra for pyrrhotite and chalcopyrite in Figure 1B. In these cases, the composition for each mineral could be determined by reducing the data over the two time-intervals separately, although this was not done here.

\section{Data reduction}

Each of the collected spectra of time-resolved countrate data for an analyte was examined, and time inter- 

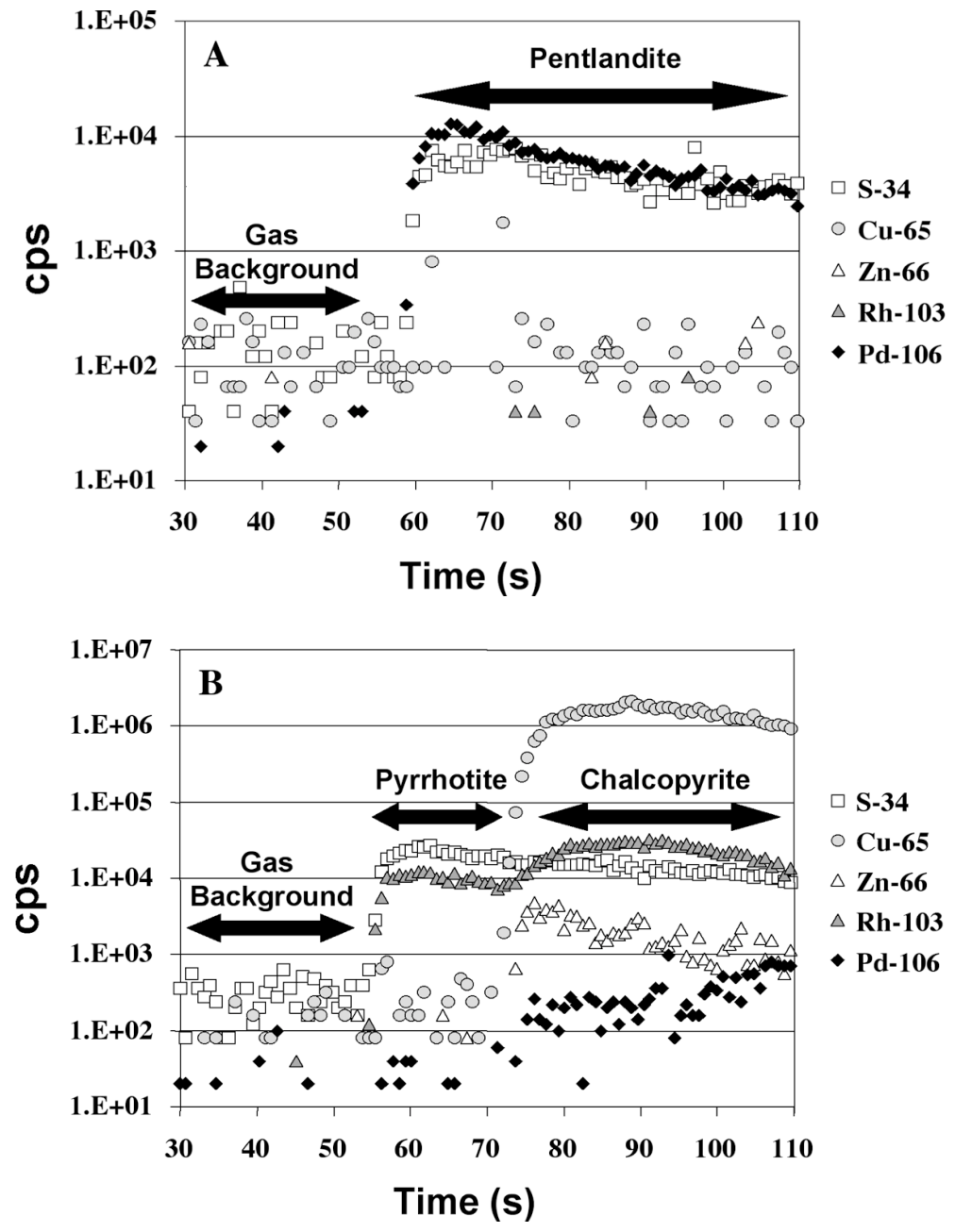

FIG. 1. Time-resolved laser-ablation count-rate spectra for selected isotopes in (A) pentlandite and (B) pyrrhotite and chalcopyrite. Laser on at 55-60 s mark in each case. Symbols used: open square: ${ }^{34} \mathrm{~S}$, shaded circle: ${ }^{65} \mathrm{Cu}$, open triangle: ${ }^{66} \mathrm{Zn}$, shaded triangle: ${ }^{103} \mathrm{Rh}$, and black diamond: ${ }^{106} \mathrm{Pd}$.

vals with the most uniform signals were selected for integration using MUN's in-house LAMTRACE spreadsheet program. The data were carefully evaluated for possible fractionation between $\mathrm{S}$ and the PGE during ablation, which was found to be negligible. The program was also used to subtract the gas background, apply the internal-standard correction for drift in instrument sensitivity during the analytical session, and perform calculations converting count rates into concentrations by reference to the synthetic sulfide standards. These procedures were described by Longerich et al. (1996). The error associated with the method is estimated to be better than $10 \%$ relative, based on repro- ducibility of results for various reference materials measured from day to day over several months in our laboratory. For the spot sizes used in this study, the limits of detection were typically $<0.1 \mathrm{ppm}$ for the light PGE, and $<0.01 \mathrm{ppm}$ for the heavy PGE.

Spectral interferences of transition metal argides on $\mathrm{Pd}, \mathrm{Rh}$ and $\mathrm{Ru}$ can be significant for LAM analyses of PGE in sulfides (Sylvester 2001). LAMTRACE does not correct for spectral interferences, so the backgroundsubtracted count-rate data were exported to another spreadsheet for the subtraction of ${ }^{59} \mathrm{Co}^{40} \mathrm{Ar}$ from ${ }^{99} \mathrm{Ru}$ and ${ }^{63} \mathrm{Cu}^{40} \mathrm{Ar}$ from ${ }^{103} \mathrm{Rh}$. Count rates for $\mathrm{Zn}$ and $\mathrm{Cd}$ in the sulfides were sufficiently low that interferences of 
${ }^{66} \mathrm{Zn}^{40} \mathrm{Ar}$ and ${ }^{106} \mathrm{Cd}$ on ${ }^{106} \mathrm{Pd}$, and ${ }^{68} \mathrm{Zn}^{40} \mathrm{Ar}$ and ${ }^{108} \mathrm{Cd}$ on ${ }^{108} \mathrm{Pd}$, were trivial and could be ignored.

Corrections for ${ }^{63} \mathrm{Cu}^{40} \mathrm{Ar}$ on ${ }^{103} \mathrm{Rh}$ were generally less than $15 \%$, with many samples requiring no correction. In the few cases where corrections of $>50 \%$ were required, most notably for the analyses on chalcopyrite, $\mathrm{Rh}$ data are not reported. Count rates of ${ }^{63} \mathrm{Cu}^{40} \mathrm{Ar}$ were calculated by assuming that ${ }^{65} \mathrm{Cu}^{40} \mathrm{Ar}$ is responsible for the "excess" counts measured for ${ }^{105} \mathrm{Pd}$, as compared to that expected for ${ }^{105} \mathrm{Pd}$ based on the count rate of ${ }^{106} \mathrm{Pd}$ in the sample and the ratio of ${ }^{105} \mathrm{Pd} /{ }^{106} \mathrm{Pd}$ in the $\mathrm{Cu}$-free $\mathrm{Pd}$ standard. Count rates for ${ }^{63} \mathrm{Cu}^{40} \mathrm{Ar}$ were then calculated from the derived ${ }^{65} \mathrm{Cu}^{40} \mathrm{Ar}$ using the known natural ${ }^{63} \mathrm{Cu} /{ }^{65} \mathrm{Cu}$ value.

Corrections for cobalt argide on ${ }^{99} \mathrm{Ru}$ are very difficult to make accurately because other isotopes of $\mathrm{Ru}$ are also compromised by spectral interferences, notably ${ }^{101} \mathrm{Ru}$ and ${ }^{102} \mathrm{Ru}$ by nickel argides. In this study, the corrections were made by assuming that all of the apparent ${ }^{99} \mathrm{Ru}$ measured in eight different Ru-poor, Corich samples run during two of the five three analytical days was, in fact, ${ }^{59} \mathrm{Co}^{40} \mathrm{Ar}$. Using the average ${ }^{59} \mathrm{Co}^{40} \mathrm{Ar} /$ ${ }^{59} \mathrm{Co}$ value of $0.00145 \pm 0.00009$ of these eight samples, count rates for ${ }^{59} \mathrm{Co}^{40} \mathrm{Ar}$ were calculated from the measured ${ }^{59} \mathrm{Co}$ count rates of the other samples run on the same two days and subtracted from their measured count-rates for ${ }^{99} \mathrm{Ru}$. This approach will significantly overcorrect for the cobalt argide interference only if there is about $0.1 \mathrm{ppm}$ or more of $\mathrm{Ru}$ in each of the eight samples. Corrections for ${ }^{59} \mathrm{Co}^{40} \mathrm{Ar}$ on ${ }^{99} \mathrm{Ru}$, derived in this manner, generally amounted to $10-40 \%$, excluding a few samples requiring corrections in excess of $50 \%$.

\section{Results AND Discussion}

\section{Homogeneity of fused pyrrhotite standards}

Table 1 gives the results of the $\mathrm{Pd}, \mathrm{Rh}$ and Ru analyses of the fused pyrrhotite standards, Po-2, Po-5 and Po- 8 , determined by LAM on $50 \mu \mathrm{m}$ spots, using the sintered pyrrhotite standards of Ballhaus \& Sylvester (2000). For the Po-2 standard, spiked with Pd, the ${ }^{105} \mathrm{Pd}$, ${ }^{106} \mathrm{Pd}$ and ${ }^{108} \mathrm{Pd}$ isotopes were measured on 16 spots in one session on one day, and then on 10 more spots in another session on another day. The mean values for each isotope in each session range from 728 to $756 \mathrm{ppm}$, with RSD of $\sim 4-9 \%$. The grand average of all six means is $746 \pm 10 \mathrm{ppm}$ ( $1 \% \mathrm{RSD})$. We initially found the range of values obtained for all three Pd isotopes in session \#1 (Table 1) to be quite large (up to $400 \mathrm{ppm}$ ) because of an outlier, which after re-examination was found to be in error because the integrated interval was selected over a burn through into epoxy. After removal of this erroneous data-set, the range of values for session \#1 was just over $100 \mathrm{ppm}$. When analyzing unknowns, the standard is analyzed twice at the start and twice at the end of a 20 -analysis session in order to verify the homogeneity of the standard. For Po-5, spiked with Rh, 16 analyses in one analytical session produced an average of $53.3 \pm$ $2.5 \mathrm{ppm}$ (5\% RSD). For Po-8, spiked with Ru, analyses of the ${ }^{99} \mathrm{Ru}$ and ${ }^{101} \mathrm{Ru}$ isotopes on six spots during one analytical session produced an average of $400 \pm 14 \mathrm{ppm}$ (4\% RSD). The homogeneity of Pd, Rh and $\mathrm{Ru}$ in the fused pyrrhotite standards is similar to that found for the sintered pyrrhotite standards (2-7\% RSD) on $70 \mu \mathrm{m}$ spots (Ballhaus \& Sylvester 2000).

\section{LAM-ICP-MS and micro-PIXE comparison for $P d$ and $R h$}

PGE measurements made by LAM-ICP-MS and micro-PIXE in the natural sulfides are given in Tables 2, 3 and 4 and shown in Figures 2 and 3. The results of the two methods are quite comparable for Pd and $\mathrm{Rh}$. For example, nine analyses of pentlandite for Pd gave from $-10.3 \%$ to $+18.7 \%$ over a range from 55 to 248 ppm Pd (Table 4). In the case of Rh in pyrrhotite (Table 3 ), where concentrations are much lower ( 0.3 to 23 $\mathrm{ppm})$, the differences are somewhat larger: $79 \%$ of the results $(n=19)$ lie within $-33 \%$ and $+30 \%$. Only six grains of chalcopyrite were analyzed, with similar results for Pd by both methods where the concentrations were above the PIXE limit of detection. Results for ruthenium in pyrrhotite (Table 3) could not be compared because concentration levels were below detection levels for micro-PIXE, and many of the LAM analyses for $\mathrm{Ru}$ were compromised by large spectral interferences of cobalt and nickel argides.

The reasonable concordance of $\mathrm{Pd}$ and $\mathrm{Rh}$ results by LAM-ICP-MS and micro-PIXE is encouraging, given the difficulty of placing the $35-40 \mu \mathrm{m}$ laser spot exactly on the area where the micro-PIXE analysis was

\begin{tabular}{|c|c|c|c|c|c|}
\hline Session & $\begin{array}{c}\text { Measured } \\
\text { isotope }\end{array}$ & $\mathrm{N}$ & $\begin{array}{l}\text { Range } \\
(\mathrm{ppm})\end{array}$ & $\begin{array}{l}\text { Mean } \\
(\mathrm{ppm})\end{array}$ & $\begin{array}{c}\% \\
\text { RSD }\end{array}$ \\
\hline \multicolumn{6}{|c|}{ Po-2 } \\
\hline \multirow[t]{3}{*}{$\# 1$} & ${ }^{105} \mathrm{Pd}$ & 15 & $700-789$ & 746 & 4.1 \\
\hline & ${ }^{106} \mathrm{Pd}$ & 15 & $680-783$ & 743 & 5.5 \\
\hline & ${ }^{108} \mathrm{Pd}$ & 15 & $671-756$ & 728 & 5.0 \\
\hline \multirow[t]{3}{*}{$\# 2$} & ${ }^{105} \mathrm{Pd}$ & 10 & $638-820$ & 756 & 7.7 \\
\hline & ${ }^{106} \mathrm{Pd}$ & 10 & $628-817$ & 748 & 8.1 \\
\hline & ${ }^{108} \mathrm{Pd}$ & 10 & $625-827$ & 756 & 8.5 \\
\hline \multicolumn{6}{|c|}{ Po-5 } \\
\hline$\# 1$ & ${ }^{103} \mathrm{Rh}$ & 16 & $48.3-56.7$ & 53.3 & 4.7 \\
\hline \multicolumn{6}{|c|}{ Po-8 } \\
\hline \multirow[t]{2}{*}{$\# 1$} & ${ }^{99} \mathrm{Ru}$ & 6 & $346-419$ & 389 & 8.2 \\
\hline & ${ }^{101} \mathrm{Ru}$ & 6 & $371-453$ & 410 & 8.4 \\
\hline
\end{tabular}

$\mathrm{N}$ : number of spot analyses. RSD: relative standard deviation. Calibrated using sintered pyrrhotite standards of Ballhaus \& Sylvester (2000). 
done (since there are no physical marks), the greater volumes of sample analyzed by LAM (by more than ten times), and the probable trace-element heterogeneity of the grains. The concordance of results is evidence for the accuracy of the LAM-ICP-MS method for trace PGE, which is limited by the accuracy of the calibration and homogeneity of the standards used for LAM-ICPMS analyses. Because the micro-PIXE method has been shown to provide accurate and precise PGE measurements (Cabri \& Campbell 1998, and references therein),
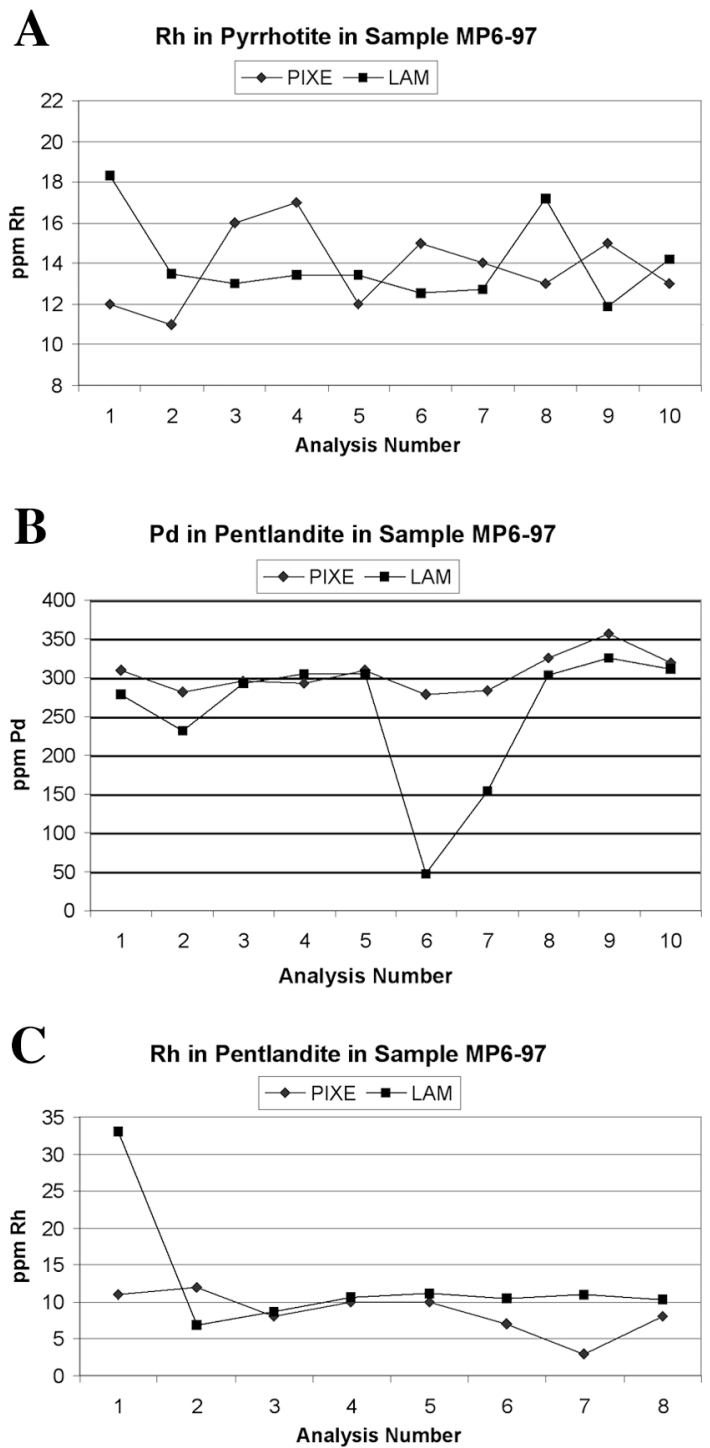

FIG. 2. Comparison of LAM-ICP-MS and micro-PIXE results in Noril'sk sample MP6-97. (A) Rh in pyrrhotite, (B) $\mathrm{Pd}$ in pentlandite, and $(\mathrm{C}) \mathrm{Rh}$ in pentlandite. verification of prospective LAM standards for homogeneity might be done by micro-PIXE. However, this will only be possible for the light PGE, for which microPIXE has detection limits of $\sim 5 \mathrm{ppm}$. LAM standards for the PGE will have optimal concentrations of $\sim 10$ $50 \mathrm{ppm}$, balancing the need for high count-rates and acceptable precision against the necessity to keep instrument background-levels sufficiently low for subppm measurements in natural samples. Unfortunately, one cannot make precise measurements of heavy PGE below $50 \mathrm{ppm}$ with the micro-PIXE technique.

\section{ConClusions}

Distler et al. (1999) and Cabri et al. (2002), among others, have found that pyrrhotite is a major carrier of $\mathrm{Rh}$ at Noril'sk, whereas pentlandite is the major repository for Pd and a secondary host for $\mathrm{Rh}$ and $\mathrm{Ru}$. The results presented here in Tables 2-4 can extend these observations. Pyrrhotite in the two Noril'sk samples is strongly depleted in $\mathrm{Pd}(\leq 1 \mathrm{ppm})$, but one sample contains significant amounts of $\mathrm{Ru}(1-5 \mathrm{ppm})$, similar to what was found in pentlandite ( $3.6 \mathrm{ppm}$ average) by Cabri et al. (2002). Platinum is somewhat more enriched in pentlandite than in pyrrhotite ( $2-5$ versus $0.1-2 \mathrm{ppm})$, but iridium is more enriched in pyrrhotite $(\sim 1.1-1.6$ $\mathrm{ppm}$ ) than in pentlandite (mostly $<1 \mathrm{ppm})$. On the other
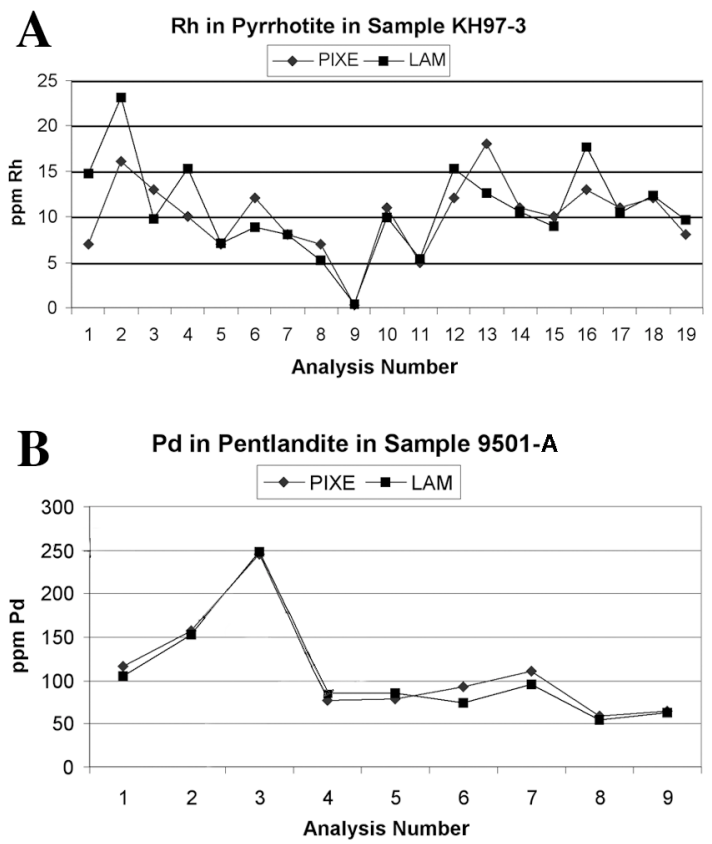

FIG. 3. Comparison of LAM-ICP-MS and micro-PIXE results in (A) Noril'sk sample KH97-3, Rh in pyrrhotite, and (B) Talnakh sample 9501-A, Pd in pentlandite. 
hand, osmium $(<0.5 \mathrm{ppm})$ is comparably enriched in both minerals. The chalcopyrite sample from Noril'sk contains trivial amounts of all PGE except for Pd (6.6$15 \mathrm{ppm})$. The Talnakh pentlandite is enriched in $\mathrm{Pd}(60$ $250 \mathrm{ppm})$ but surprisingly depleted in $\mathrm{Rh}(\sim 1 \mathrm{ppm}$ or less) compared to the Noril'sk samples. Pt, Ir and Os in Talnakh pentlandite, pyrrhotite and chalcopyrite are also present at very low levels $(\sim 5-200 \mathrm{ppb})$, reported here for the first time. We anticipate that the LAM-ICP-MS technique will gain a wide level of acceptance for the determination of trace PGE in sulfides ores, concentrates and metallurgical products. This study has also demonstrated that potential standards need to be carefully evaluated for homogeneity, as it is difficult to synthesize highly homogeneous sulfides.

\section{ACKNOWLEDGEMENTS}

The MUN LAM-ICP-MS facility is supported by NSERC through Major Facilities Access funding. LJC

TABLE 2. DATA ON Pd, Rh, Pt, Ir AND Os IN PYRRHOTITE, PENTLANDITE AND CHALCOPYRITE IN SAMPLE MP6-97 (NORIL'SK)

\begin{tabular}{|c|c|c|c|c|c|c|c|}
\hline \multicolumn{2}{|c|}{$\begin{array}{c}\mathrm{Pd} \\
\mathrm{ppm}\end{array}$} & \multicolumn{2}{|c|}{$\begin{array}{l}\mathrm{Rh} \\
\mathrm{ppm}\end{array}$} & \multirow{2}{*}{$\begin{array}{c}\% \mathrm{ArCu} \\
\text { correction } \\
-\end{array}$} & \multirow{2}{*}{$\begin{array}{c}\begin{array}{c}\text { Pt } \\
\text { ppm }\end{array} \\
\text { LAM }\end{array}$} & \multirow{2}{*}{$\begin{array}{c}\begin{array}{c}\mathrm{Ir} \\
\mathrm{ppm}\end{array} \\
\text { LAM }\end{array}$} & \multirow{2}{*}{$\begin{array}{c}\begin{array}{c}\text { Os } \\
\mathrm{ppm}\end{array} \\
\text { LAM }\end{array}$} \\
\hline PIXE & LAM & PIXE & LAM & & & & \\
\hline
\end{tabular}

\begin{tabular}{|c|c|c|c|c|c|c|c|c|}
\hline \multicolumn{9}{|c|}{ Pyrrhotite } \\
\hline Po-40 & $<\mathrm{LOD}$ & 0.28 & 12 & 18.3 & 0 & 0.42 & 1.41 & n.m. \\
\hline Po-38 & $<$ LOD & 0.45 & 11 & 13.5 & 0 & 0.29 & 1.38 & n.m. \\
\hline Po-41 & $<\mathrm{LOD}$ & 0.41 & 16 & 13.0 & 1.1 & 0.54 & 1.13 & n.m. \\
\hline Po-37 & $<\mathrm{LOD}$ & $<0.10$ & 17 & 13.4 & 0.1 & 0.10 & 1.24 & n.m. \\
\hline Po-39 & $<\mathrm{LOD}$ & $<0.08$ & 12 & 13.4 & 0 & 0.65 & 1.30 & n.m. \\
\hline Po-32 & $<\mathrm{LOD}$ & 0.27 & 15 & 12.5 & 0 & 1.87 & 1.42 & n.m. \\
\hline Po-33 & $<\mathrm{LOD}$ & $<0.12$ & 14 & 12.7 & 0 & 1.79 & 1.48 & n.m. \\
\hline Po-36 & $<\mathrm{LOD}$ & 1.01 & 13 & 17.2 & 0.5 & 0.50 & 1.58 & 0.48 \\
\hline Po-35 & $<\mathrm{LOD}$ & 0.63 & 15 & 11.9 & 10.9 & 0.63 & 1.41 & 0.39 \\
\hline Po-34 & $<$ LOD & 0.51 & 13 & 14.2 & 3.4 & 0.52 & 1.41 & 0.50 \\
\hline \multicolumn{9}{|c|}{ Pentlandite } \\
\hline Pn-23 & 310 & 278 & 11 & 33.1 & 0.3 & 2.21 & 1.47 & n.m. \\
\hline $\mathrm{Pn}-22$ & 281 & 231 & 12 & 6.81 & 22.5 & 2.06 & 0.96 & n.m. \\
\hline Pn-24 & 295 & 292 & 8 & 8.72 & 12.9 & 4.93 & 0.98 & n.m. \\
\hline Pn-26 & 292 & 304 & 10 & 10.6 & 0.3 & 2.31 & 1.02 & n.m. \\
\hline Pn-25 & 310 & 304 & 10 & 11.1 & 0.4 & 3.60 & 1.18 & n.m. \\
\hline Pn-28* & 278 & 47.4 & 19 & n.r. & $>50$ & 1.30 & 1.00 & 0.28 \\
\hline Pn-27* & 283 & 153 & 9 & n.r. & $>50$ & 3.56 & 0.23 & 0.09 \\
\hline Pn-29 & 325 & 302 & 7 & 10.5 & 0.4 & 3.46 & 0.75 & 0.35 \\
\hline $\mathrm{Pn}-30^{* *}$ & 356 & 324 & 3 & 11.0 & 1.6 & 4.62 & 0.89 & 0.27 \\
\hline Pn-31 & 318 & 310 & 8 & 10.3 & 0.2 & 3.96 & 0.96 & 0.34 \\
\hline \multicolumn{9}{|c|}{ Chalcopyrite } \\
\hline $\mathrm{Cp}-45$ & 13 & 11.4 & $<\mathrm{LOD}$ & n.r. & $>50$ & 0.02 & $<0.006$ & $<0.01$ \\
\hline $\mathrm{Cp}-45 \mathrm{a} * * *$ & 13 & 12.9 & $<\mathrm{LOD}$ & n.r. & $>50$ & 0.005 & $<0.007$ & $<0.004$ \\
\hline $\mathrm{Cp}-44$ & 9 & 14.8 & $<\mathrm{LOD}$ & n.r. & $>50$ & 0.20 & 0.005 & $<0.004$ \\
\hline $\mathrm{Cp}-42$ & $<$ LOD & 6.56 & $<\mathrm{LOD}$ & n.r. & $>50$ & $<0.01$ & $<0.005$ & 0.003 \\
\hline
\end{tabular}

* LAM analysis at edge of sulfide in contact with magnetite. ${ }^{* *}$ LAM analysis not on exact spot as PIXE analysis. *** LAM analysis repeated. Pd from ${ }^{106} \mathrm{Pd}$ isotope, $\mathrm{Pt}$ from ${ }^{195} \mathrm{Pt}$ isotope, Ir from ${ }^{193} \mathrm{Ir}$ isotope, and Os from ${ }^{189} \mathrm{O}$ s isotope. LOD: limit of detection; n.m.: not measured; n.r.: not reported, as interference correction is greater than $50 \%$. is grateful to Falconbridge Limited for partial financial support during a two-week visit at MUN, as well as to personnel at the University of Guelph for the excellent

TABLE 3. DATA ON Pd, Rh AND Ru IN PYRRHOTITE IN SAMPLE KH97-3 (NORIL'SK)

\begin{tabular}{|c|c|c|c|c|c|c|}
\hline & \multirow{2}{*}{$\frac{\text { Pd (ppm) }}{\text { LAM }}$} & \multicolumn{3}{|c|}{$\mathrm{Rh}$ (ppm) } & \multicolumn{2}{|c|}{$\mathrm{Ru}(\mathrm{ppm})$} \\
\hline & & PIXE & LAM & $\begin{array}{l}\% \mathrm{ArCu} \\
\text { correction }\end{array}$ & LAM & $\begin{array}{l}\% \text { ArCo } \\
\text { correction }\end{array}$ \\
\hline Po-167 & n.m. & 7 & 14.7 & 0 & 3.0 & 19 \\
\hline Po-161 & n.m. & 16 & 23.1 & 0 & n.r. & $>50$ \\
\hline Po-169 & n.m. & 13 & 9.81 & 0 & 1.2 & 31 \\
\hline Po-164 & n.m. & 10 & 15.3 & 0 & 3.0 & 21 \\
\hline Po-165 & n.m. & 7 & 7.15 & 0 & n.r. & $>50$ \\
\hline Po-171 & n.m. & 12 & 8.80 & 0 & 1.2 & 43 \\
\hline Po-180 & n.m. & 8 & 8.04 & 0 & 1.3 & 33 \\
\hline Po-179 & n.m. & 7 & 5.19 & 0 & 2.7 & 18 \\
\hline Po-183 & n.m. & 0.3 & 0.38 & 45.3 & n.r. & $>50$ \\
\hline Po-184 & n.m. & 11 & 9.88 & 0 & 2.1 & 20 \\
\hline Po-185 & n.m. & 5 & 5.31 & 0 & n.r. & $>50$ \\
\hline Po-186 & n.m. & 12 & 15.3 & 0 & 2.9 & 11 \\
\hline Po-187 & n.m. & 18 & 12.6 & 1.0 & 1.5 & 25 \\
\hline Po-208 & $<0.02$ & 11 & 10.6 & 0 & 2.4 & 14 \\
\hline Po-204 & 0.10 & 10 & 9.06 & 0 & 2.3 & 12 \\
\hline Po-205 & $<0.06$ & 13 & 17.7 & 0 & 4.6 & 8 \\
\hline Po-198 & 0.81 & 11 & 10.4 & 0 & 1.7 & 23 \\
\hline Po-195 & 1.32 & 12 & 12.3 & 0 & 2.0 & 16 \\
\hline Po-192 & 0.42 & 8 & 9.58 & 3.1 & 1.7 & 23 \\
\hline
\end{tabular}

Pd from ${ }^{106} \mathrm{Pd}$ isotope, $\mathrm{Ru}$ from ${ }^{99} \mathrm{Ru}$ isotope. n.m.: not measured; $\mathrm{n} . \mathrm{r} .:$ not reported, as interference correction is greater than $50 \%$.

TABLE 4. DATA ON Pd, Rh, Pt, Ir AND Os IN PENTLANDITE, PYRRHOTITE AND CHALCOPYRITE IN SAMPLE 9501-A (TALNAKH)

\begin{tabular}{|c|c|c|c|c|c|c|c|}
\hline & \multicolumn{2}{|c|}{$\begin{array}{c}\mathrm{Pd} \\
\mathrm{ppm}\end{array}$} & \multirow{2}{*}{$\begin{array}{c}\begin{array}{c}\mathrm{Rh} \\
\mathrm{ppm}\end{array} \\
\\
\mathrm{LAM}\end{array}$} & \multirow{2}{*}{$\begin{array}{c}\% \mathrm{ArCu} \\
\text { correction }\end{array}$} & \multirow{2}{*}{$\begin{array}{c}\begin{array}{c}\text { Pt } \\
\text { ppm }\end{array} \\
\text { LAM }\end{array}$} & \multirow{2}{*}{$\begin{array}{c}\begin{array}{c}\text { Ir } \\
\text { ppm }\end{array} \\
\text { LAM }\end{array}$} & \multirow{2}{*}{$\begin{array}{c}\begin{array}{c}\text { Os } \\
\text { ppm }\end{array} \\
\text { LAM }\end{array}$} \\
\hline & PIXE & LAM & & & & & \\
\hline \multicolumn{8}{|c|}{ Pentlandite } \\
\hline Pn-172 & 117 & 105 & 0.87 & 6.7 & 0.10 & 0.021 & $<0.005$ \\
\hline Pn-173 & 157 & 152 & 0.51 & 0.1 & 0.17 & 0.014 & $<0.005$ \\
\hline Pn-174 & 245 & 248 & 0.48 & 1.4 & 0.19 & $<0.011$ & 0.006 \\
\hline Pn-171 & 77 & 84.9 & $<0.07$ & 0 & 0.018 & 0.003 & $<0.005$ \\
\hline Pn-170 & 79 & 85.5 & 0.024 & 0.5 & 0.020 & 0.002 & $<0.005$ \\
\hline Pn-165 & 92 & 74.8 & 0.38 & 29.2 & 0.037 & 0.011 & $<0.005$ \\
\hline Pn-166 & 111 & 94.9 & $<0.08$ & 0 & 0.10 & $<0.008$ & 0.007 \\
\hline Pn-169 & 59 & 54.5 & 0.66 & 0 & 0.023 & $<0.006$ & $<0.005$ \\
\hline Pn-168 & 64 & 62.4 & 1.17 & 18.0 & 0.014 & 0.016 & $<0.005$ \\
\hline \multicolumn{8}{|c|}{ Pyrrhotite } \\
\hline Po-157 & $<$ LOD & $<0.19$ & 0.78 & 0 & 0.014 & 0.014 & $<0.017$ \\
\hline Po- 156 & $<\mathrm{LOD}$ & 0.28 & 0.75 & 0 & $<0.012$ & 0.017 & $<0.023$ \\
\hline \multicolumn{8}{|c|}{ Chalcopyrite } \\
\hline $\mathrm{Cp}-181$ & $<\mathrm{LOD}$ & 0.42 & n.r. & $>50$ & $<0.003$ & $<0.001$ & $<0.016$ \\
\hline $\mathrm{Cp}-180$ & $<\mathrm{LOD}$ & 0.45 & n.r. & $>50$ & $<0.008$ & $<0.006$ & $<0.018$ \\
\hline Cp-182 & $<$ LOD & 0.34 & n.r. & $>50$ & 0.004 & $<0.009$ & $<0.011$ \\
\hline
\end{tabular}

Pd from ${ }^{106} \mathrm{Pd}$ isotope, Pt from ${ }^{195} \mathrm{Pt}$ isotope, Ir from ${ }^{193} \mathrm{Ir}$ isotope and Os from ${ }^{189} \mathrm{Os}$ isotope. LOD: limit of detection. n.r.: not reported, as interference correction is greater than $50 \%$. 
handling of the micro-PIXE analyses. The synthesis of pyrrhotite standards was carried out using laboratory facilities of the Canada Center for Mineral and Energy Technology with the financial support provided by NSERC, through a NATO postdoctoral fellowship to AP (1999-2001). AP is also very grateful to Prof. D.H. Watkinson (Carleton University), who kindly hosted her in his laboratory during tenure of the NATO fellowship, and who contributed the financial and scientific support for her experimental work. The authors are also grateful for the comments of Guest Associate Editor Simon Jackson, referees Chris Ryan, Kreshimir Malitch, Marc Norman and W. Ian Ridley, but are solely responsible for the paper.

\section{REFERENCES}

Alard, O., Griffin, W.L., Lorand, J.P., Jackson, S.E. \& O'REILly, S.Y. (2000): Non-chondritic distribution of the highly siderophile elements in mantle sulphides. Nature 407, 891-894.

Ballhaus, C. \& Sylvester, P. (2000): Noble metal enrichment processes in the Merensky Reef, Bushveld Complex. J. Petrol. 41, 545-561.

CABRI, L.J. (1998): A micro-PIXE study of trace elements in sulphides from the Noril'sk area, Russia. CANMET, Mining and Mineral Sciences Laboratories, Rep. MMSL 98070 (CR).

\& CAMPBELL, J.L. (1998): The proton microprobe in ore mineralogy (micro-PIXE technique). In Modern Approaches to Ore and Environmental Mineralogy (L.J. Cabri \& D.J. Vaughan, eds.). Mineral. Assoc. Can., Short Course Vol. 27, 181-198.

Wilson, J.M.D., Distler, V.V., Kingston, D., NEJEDLY, Z. \& SLUZHENIKIN, S.F. (2002): Mineralogical distribution of trace platinum-group elements in major sulphide minerals from the disseminated sulphide ores of the Noril'sk 1 layered intrusion. Trans. Inst. Mining Metall. I Proc. Austral. Inst. Mining Metall. (Sect. B: Appl. Earth Sci.) 111, B15-22.

Chen, ZhongXing, Fryer, B.J., LONGERICH, H.P. \& JACKSON, S.E. (1996): Determination of the precious metals in milligram samples of sulfides and oxides using inductively coupled plasma mass spectrometry after ion exchange preconcentration. J. Anal. Atom. Spectrom. 11, 805-809.

DisTLER, V.V. (1994): Platinum mineralization of the Noril'sk deposits. In Proceedings of the Sudbury - Noril'sk Symposium (P.C. Lightfoot \& A.J. Naldrett, eds.). Ontario Geol. Surv., Spec. Vol. 5, 243-260.

SluZhenikin, S.F., CABRi, L.J., KRIVOLUTSKaya, N. A., Turovtsev, D. M. Golovanova, T.A., Mokhov, A.V.,
Knauf, V.V. \& OleshKeVich, O.I. (1999): Platinum ores of the Noril'sk layered intrusions: magmatic and fluid concentration ratio of noble metals. Geology of Ore Deposits 41(3), 214-237.

GEnkin, A.D. (1968): PGM and Their Associations in the Noril'sk Cu-Ni Ores. Nauka, Moscow. Russia (in Russ.).

JACKSON, S.E., LONGERICH, H.P., DUNNING, G.R. \& FRYER, B.J. (1992): The application of laser-ablation microprobe - inductively coupled plasma - mass spectrometry (LAMICP-MS) to in situ trace-element determinations in minerals. Can. Mineral. 30, 1049-1064.

Kozyrev, S.M., Komarova, M.Z., Emelina, L.N., OleshKevich, O.I., Yakovleva, O.A., Lyalinov, D.V. \& MAXIMOV, V.I. (2002): The mineralogy and behaviour of PGM during processing of the Noril'sk-Talnakh PGE-Cu$\mathrm{Ni}$ ores. In The Geology, Geochemistry, Mineralogy and Mineral Beneficiation of Platinum-Group Elements (L.J. Cabri, ed.). Can. Inst. Mining, Metall. and Petroleum, Spec. Vol. 54, 757-791.

LAFLAMME, J.H.G. (2000): Electron microprobe analyses of pentlandite and pyrrhotite from Noril'sk, Russia. CANMET-MMSL Rep. M-5457.

LASTRA, R., WiLSON, J.M.D. \& CABRI, L.J. (1999): Automated gold search and applications in process mineralogy. Trans. Inst. Mining Metall., Sect. C 108, C75-C84.

LIKHACHEV, A.P. (1999): Characteristics of the distribution and concentration of platinum metals and other ore components in Talnakh intrusions. In Platinum of Russia. IV. Problems of Development of the Platinum Metals Resource Base in the XXI Century (Mineralogy, Genesis, Technology), Geoinformmark, Moscow, Russia (86-100; in Russ.).

LONGERICH, H.P., JACKSON, S.E. \& GÜNTHER, D. (1996): Laser ablation - inductively coupled plasma mass spectrometric transient signal data acquisition and analyte concentration calculation. J. Anal. At. Spectrom. 11, 899-904.

McMahon, G. \& CABRI, L.J. (1998): The SIMS technique in ore mineralogy. In Modern Approaches to Ore and Environmental Mineralogy (L.J. Cabri \& D.J. Vaughan, eds.). Mineral. Assoc. Can., Short Course Vol. 27, 199-223.

Sylvester, P.J. (2001): A practical guide to platinum-group element analysis of sulphides by laser ablation ICPMS. In Laser-Ablation - ICPMS in the Earth Sciences: Principles and Applications (P. Sylvester, ed.). Mineral. Assoc. Can., Short Course 29, 203-211.

Received July 20, 2002, revised manuscript accepted February 6, 2003. 